\title{
Sustainable Intensification of Global Agronomic Output
}

\author{
Niels Dybro ${ }^{1} \&$ Alan Christopher Hansen ${ }^{1}$ \\ ${ }^{1}$ Department of Agricultural and Biological Engineering, University of Illinois at Urbana-Champaign, Urbana, \\ Illinois, USA \\ Correspondence: Niels Dybro, Department of Agricultural and Biological Engineering, University of Illinois at \\ Urbana-Champaign, Urbana, Illinois, USA. Tel: 1-309-738-2598. E-mail: ndybro@hotmail.com
}

Received: November 14, 2017

Accepted: January 24, 2018 Online Published: February 15, 2018

doi:10.5539/jas.v10n3p30

URL: https://doi.org/10.5539/jas.v10n3p30

\begin{abstract}
Agribusinesses are investigating sustainable ways to meet the predicted increased demand for food production due to an increasing world population and higher living standards. Therefore, there is a strong need to increase agronomic output. This paper will review the current state of agricultural production of the main annual top-five staple grain crops grown around the world, their current yields and harvested area averages and trends. It concludes with a discussion of which changes are needed to increase the yield in lower yielding areas of the world. Finally, there is an assessment of what level of yield increases that could be attained provided the proposed changes are made and its predicted impact on food security by 2050 .

The current yield trends and trends for harvested area, when extrapolated out to 2050, indicate crop production will increase $106 \%$. This includes an expansion of the total crop production area by $31 \%$. This increase of cropping area can be achieved by increased utilization of available, uncropped land suitable for crop production, increased double cropping, and relay intercropping, allowing for multiple crops in a calendar year.

In order to double crop production by 2050 , it is necessary to focus on growing crops where the conditions make it possible, adopt the best sustainable crop production practices and implement them as intensively as possible everywhere, and consider improved crop production machine system options to reduce risk of soil compaction, which can reduce crop yields.

With proposed changes across the world, it will be possible to exceed a doubling of food production by 2050 relative to 2005 levels, providing a reasonable high level of food security, absent wars and widespread natural disasters.
\end{abstract}

Keywords: crop production, food security, grain, machine system, soil compaction, sustainability

\section{Introduction}

The population of the earth is expected to exceed 9 billion by the year 2050 (King et al., 2017; Taheri, Azadi, \& D'Haese 2017), which puts pressure on agriculture around the world: More people will need to be fed from the land suitable for crop production, which will be in competition with more land needed for urban sprawl. Food demand is predicted to increase more rapidly than population growth due to change in dietary preferences. This effect has precipitated estimates for a need to increase the food production by $70-100 \%$ by 2050 (Borlaug, 2007; King et al., 2017). This dietary preference change is driven by a predicted growing level of prosperity. With increased prosperity comes a desire among people to include more animal protein in their diet (Dong \& Fuller, 2010). As the demand for animal protein increases, so does the need for animal feedstock, which has to come from an increase in crop production.

In order to address this issue of ever-increasing food demand from the available land area suitable for crop production, emphasis needs to be placed on increased food production per unit of land per year. Smith (2013) offers a definition for this intensification of production done in a sustainable way, or "sustainable intensification", which reads "The process of delivering more, safe, nutritious food per unit of input resource, whilst allowing the current generation to meet its needs without compromising the ability of future generations to meet their own needs." Farmers in the future need to focus on creating the most suitable, sustainable conditions for plant growth and select the most appropriate crops in order to maximize the yield and nutritional content (Green et al., 2015). Some improvements can be expected from genetics development (Jaggard, 2010). Management systems focused on increasing land productivity will increase actual yields (Hatfield \& Walthall, 2015), especially management of 
nutrients and water in order to close the yield gap where it exists around the world (Mueller et al., 2012). Increasing the number of crops grown in a single year is also a possibility based on local temperatures throughout the year and water availability, as either rain or irrigation. Such opportunities for increasing harvested area through double or triple cropping or relay intercropping are not fully utilized. Ray and Foley (2013) state that there are large harvest gaps in Latin America and Africa and globally, which amounts to an extra harvested crop every other year and theoretically would boost agricultural production by more than $44 \%$, at least in the short term. Martin-Guay et al. (2018) indicate through meta-analysys that intercropping, if implemented widely the wworld over, has the potential to increase the production by $38 \%$ alone. Godfray (2013) suggests the growth in demand will require action on food production, diet, waste and efficiency, and governance of the food system. Mauser et al. (2015) forecast through modeling with historical weather data that it is possible to satisfy the biomass needs by 2050 only through crop growth management without increasing the total global area under cultivation.

Effects of climate change are not considered in this paper because of the inconsistent reported effects. Nelson et al. (2014) report that climate change induced temperature change, but without the influence of elevated carbon dioxide levels, will cause a reduction of yields of $17 \%$, whereas Bourgault et al. (2016) report that yields of pea cultivars increase by $26 \%$ when subjected to elevated carbon dioxide concentrations in the air $(550 \mathrm{ppm})$ versus control (400 ppm) under rain fed conditions with supplemental irrigation.

This paper reviews the current state of agricultural production of the main annual top-five staple grain crops grown around the world, their current yields and harvested area averages and trends as reported to FAO from 1989-2013. It concludes with a discussion of which contextual and constrained changes are needed to increase the yield in low yielding areas. Finally, there is an assessment of what level of yield increases could be attained, provided that the contextual and constrained changes are made, and what the predicted impact will be on food security by 2050 .

\section{Top-Five Grain Yield and Production Data \& Trends}

To answer the question if yield and production trends in general will approach the needs of doubling the crop production by 2050 , a review of the yield trends for the top-five grain crops from around the world was performed. The top-five grain crops are as follows: Maize (Zea mays), rice (Oryza stavia), wheat (Triticum spp.), soybeans (Glycine max), and sorghum (Sorghum bicolor). Twenty-five years of global yield data, their trend line and associated regression equation are shown in appendix for these top-five grain crops in Figures 1-5 (FAOSTAT, 2015).

From Figure 1, it is evident that the regional maize yield is clearly highest in the United States of America, with a higher average yield than anywhere else in the world. However, the trend line rate of yield increase in the United States of America

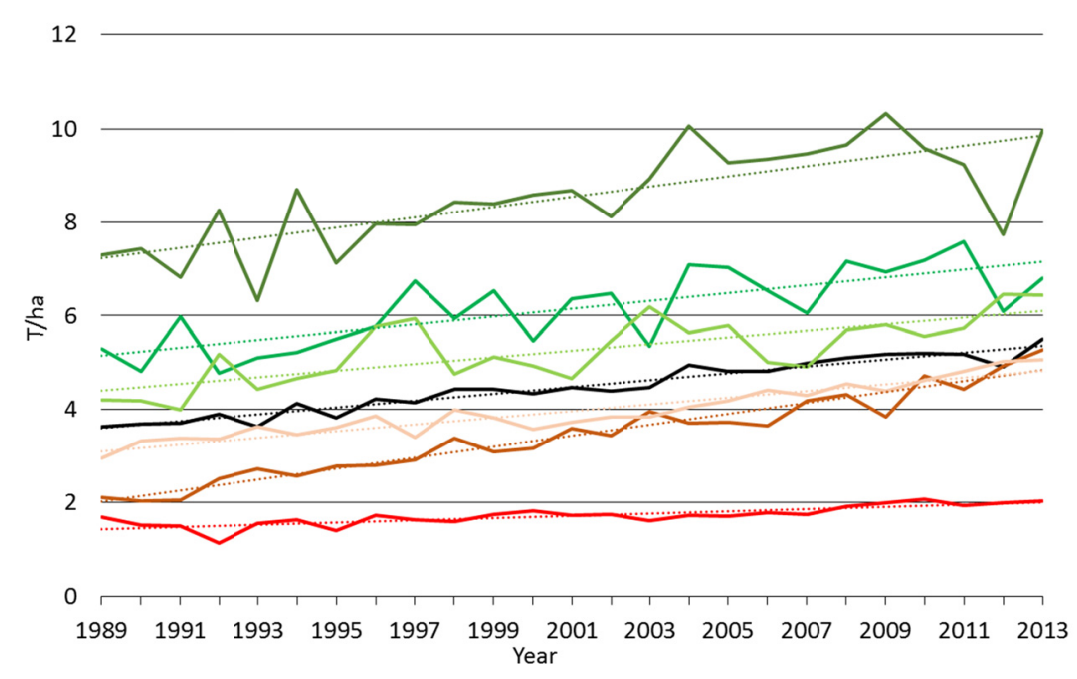

$$
\begin{aligned}
& \text { World } \\
& y=0.0737 x+3.5203 \\
& \mathrm{R}^{2}=0.9297 \\
& \text { —USA } \\
& y=0.1094 x+7.1268 \\
& \mathrm{R}^{2}=0.5775 \\
& \text {-S. America } \\
& y=0.1176 x+1.9052 \\
& R^{2}=0.9385 \\
& \text {-EU } \\
& y=0.0836 x+5.0673 \\
& \mathrm{R}^{2}=0.5731 \\
& \text { Asia } \\
& y=0.0724 x+3.0196 \\
& \mathrm{R}^{2}=0.8942 \\
& \text {-Africa } \\
& y=0.0236 x+1.4115 \\
& \mathrm{R}^{2}=0.6609 \\
& \text {-Australia } \\
& y=0.0714 x+4.3261 \\
& \mathrm{R}^{2}=0.5604
\end{aligned}
$$

Figure 1. Maize (Zea Mais) yield between 1989-2013 for the whole world and major regions with trend line and equation 
is only second in the world at $109 \mathrm{~kg} / \mathrm{ha} /$ year. South America, as a region, has the highest annual trend line rate of yield increase at $118 \mathrm{~kg} / \mathrm{ha} / \mathrm{year}$. On a worldwide level, the trend line rate of yield increase is at $74 \mathrm{~kg} / \mathrm{ha} / \mathrm{year}$, and the lowest trend line rate of yield increase is in Africa with only $24 \mathrm{~kg} / \mathrm{ha} /$ year increase per year of trend line rate of yield increase.

Figure 2 shows that rice yield is highest in Australia, but the trend line rate of yield increase is much lower, at 42 $\mathrm{kg} / \mathrm{ha} /$ year, than what is the case for the United States of America at $93 \mathrm{~kg} / \mathrm{ha} /$ year. Worldwide, the trend line rate of yield increase is $43 \mathrm{~kg} / \mathrm{ha} /$ year, same as for Asia. Again, here the lowest yielding area and the area with the lowest trend line rate of yield increase is Africa with only $25 \mathrm{~kg} / \mathrm{ha} /$ year.



$$
\begin{gathered}
y=0.0434 x+3.3934 \\
R^{2}=0.9776 \\
\text {-USA } \\
y=0.0929 x+5.9665 \\
R^{2}=0.8706 \\
\text {-S. America } \\
y=0.1132 x+2.2771 \\
R^{2}=0.9758 \\
\text { - EU } \\
y=0.0516 x+5.5383 \\
R^{2}=0.6678 \\
\quad \text { Asia } \\
y=0.0433 x+3.4683 \\
R^{2}=0.9703 \\
\text { - Africa } \\
y=0.0247 x+1.9836 \\
R^{2}=0.8754 \\
\text { - Australia } \\
y=0.0416 x+8.118 \\
R^{2}=0.0977
\end{gathered}
$$

Figure 2. Rice (Oryza stavia) yield between 1989-2013 for the whole world and major regions with trend line and equation.

The European Union dominates with respect to wheat yields as shown on Figure 3. However, their trend line rate of yield increase at $35 \mathrm{~kg} / \mathrm{ha} /$ year is lower than that of Africa at $43 \mathrm{~kg} / \mathrm{ha} /$ year. The worldwide trend line rate of yield increase is at $31 \mathrm{~kg} / \mathrm{ha} /$ year. The graph for Asia gives some rise for concern, since their trend line rate of yield increase is negative at $-9 \mathrm{~kg} / \mathrm{ha} /$ year.

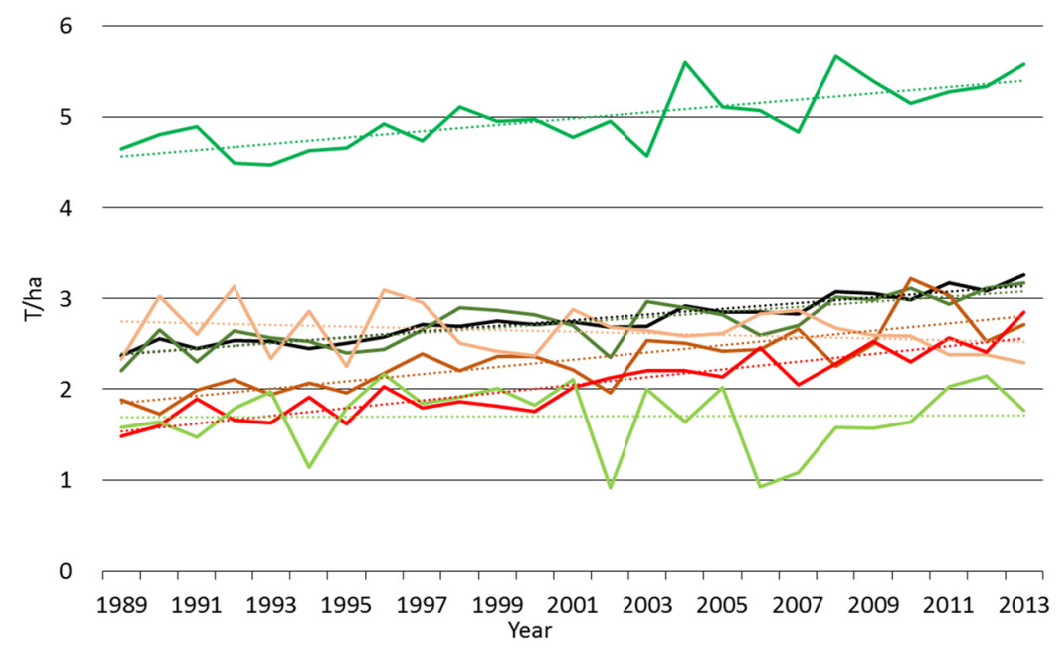

$$
\begin{gathered}
y=0.0313 x+2.3571 \\
R^{2}=0.9011 \\
\text {-USA } \\
y=0.0285 x+2.3658 \\
R^{2}=0.6098 \\
\text {-S. America } \\
y=0.0398 x+1.8113 \\
R^{2}=0.6798 \\
\text {-EU } \\
y=0.0348 x+4.5392 \\
R^{2}=0.5585 \\
\text { - Asia } \\
y=-0.0093 x+2.7597 \\
R^{2}=0.0679 \\
\text {-Africa } \\
y=0.0431 x+1.4874 \\
R^{2}=0.8177 \\
\text { A Australia } \\
y=0.0005 x+1.6943 \\
R^{2}=9 E-05
\end{gathered}
$$

Figure 3. Wheat (Triticum ssp.) yield between 1989-2013 for the whole world and major regions with trend line and equation 
In the case of soybeans, Figure 4 shows that the United States of America, the European Union, and South America are competing closely for who have the highest yield in a given year. In some years, Australia is even able to show competitive yield results. However, the trend line rate of soybean yield increase is highest for South America at $34 \mathrm{~kg} / \mathrm{ha} /$ year followed by Africa at $26 \mathrm{~kg} / \mathrm{ha} /$ year. The worldwide trend line rate of soybean yield increase is at $25 \mathrm{~kg} / \mathrm{ha} /$ year. The lowest trend line rate of yield increase is for the European Union at 3 $\mathrm{kg} / \mathrm{ha} /$ year.

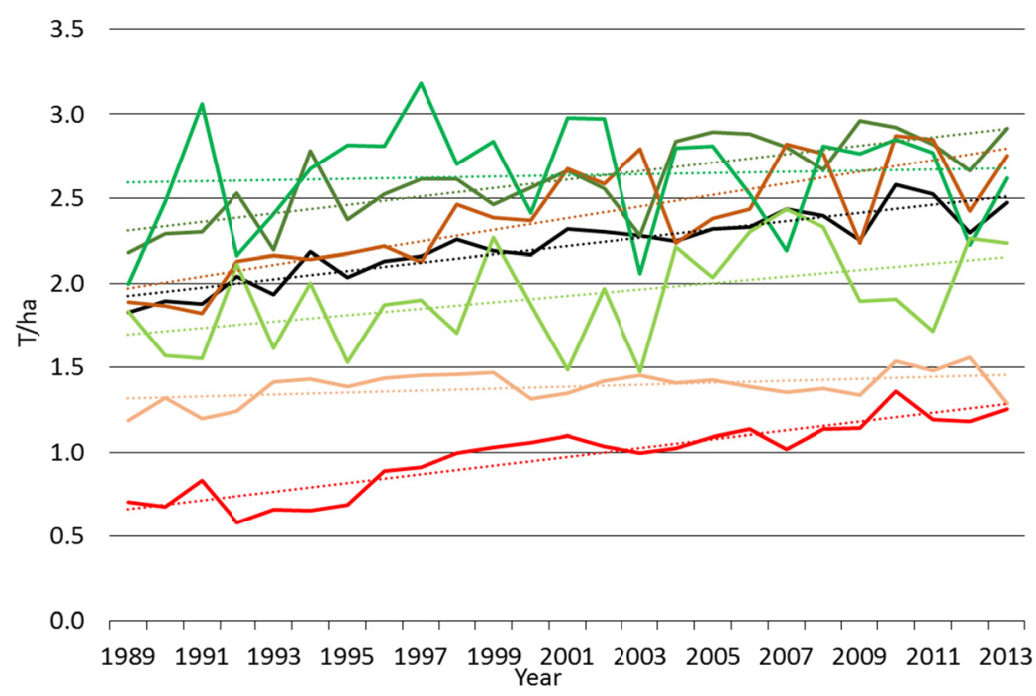

$$
\begin{gathered}
y=0.0245 x+1.8996 \\
R^{2}=0.8145 \\
\text { - USA } \\
y=0.0252 x+2.2851 \\
R^{2}=0.5882 \\
\text { - S. America } \\
y=0.0344 x+1.9351 \\
R^{2}=0.6374 \\
\text { - EU } \\
y=0.0034 x+2.5923 \\
R^{2}=0.0059 \\
\text { - Asia } \\
y=0.0059 x+1.3091 \\
R^{2}=0.2130 \\
\text { - Africa } \\
y=0.0260 x+0.6346 \\
R^{2}=0.8207 \\
y=0.0190 x+1.6757 \\
R^{2}=0.2303
\end{gathered}
$$

Figure 4. Soybean (Glycine Max) yield between 1989-2013 for the whole world and major regions with trend line and equation

The European Union has the highest yields in sorghum followed by the United States of America as shown in Figure 5 .

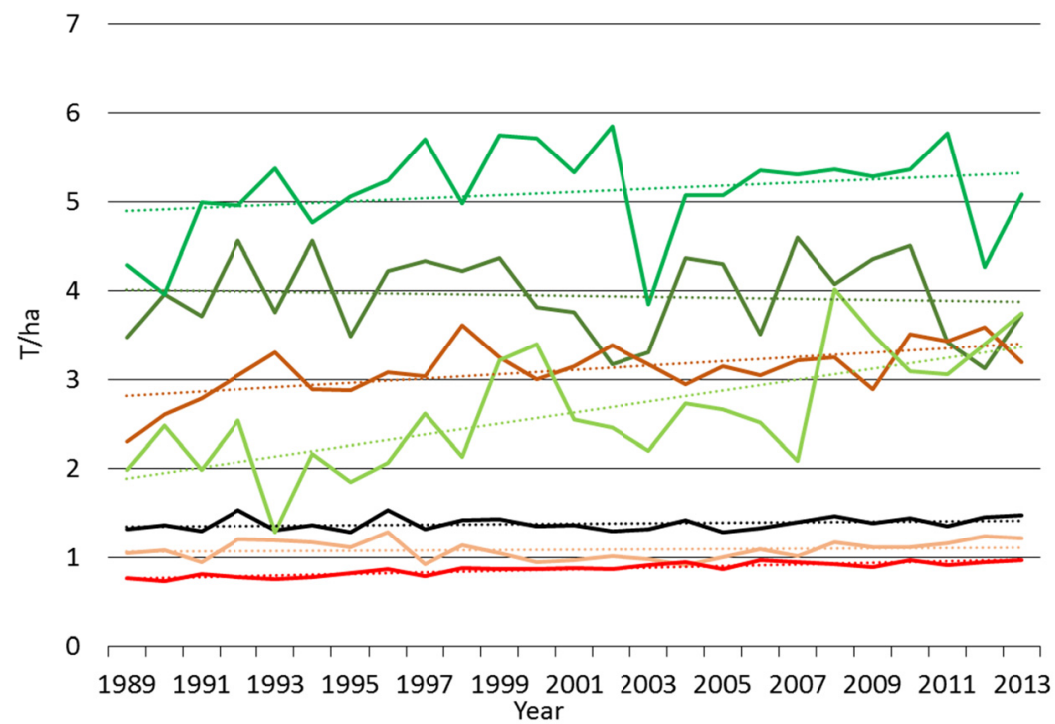

$$
\begin{gathered}
y=0.0025 x+1.3497 \\
R^{2}=0.0646 \\
\text {-USA } \\
y=-0.0057 x+4.0259 \\
R^{2}=0.0082 \\
\text { - S. America } \\
y=0.0246 x+2.7897 \\
R^{2}=0.3661 \\
\text { - EU } \\
y=0.0183 x+4.8727 \\
R^{2}=0.0624 \\
y=0.002 x+1.0584 \\
R^{2}=0.0185 \\
- \text { Africa } \\
y=0.0088 x+0.7547 \\
R^{2}=0.7968 \\
y=0.0617 x+1.8301 \\
R^{2}=0.4724
\end{gathered}
$$

Figure 5. Sorghum (Sorghum bicolor) yield between 1989-2013 for the whole world and major regions with trend line and equation 
However, Australia has the greatest trend line rate of yield increase at $62 \mathrm{~kg} / \mathrm{ha} / \mathrm{year}$ followed by South America at $25 \mathrm{~kg} / \mathrm{ha} /$ year. The worldwide trend line rate of yield increase is only $3 \mathrm{~kg} / \mathrm{ha} / \mathrm{year}$. The graph for the United States of America gives some rise for concern, since their trend line rate of yield increase is negative at -6 $\mathrm{kg} / \mathrm{ha} /$ year.

Figure 6 graphs the world yield for the top-five grains, which allows for an easy comparison view the yield trends for the top-five grains.

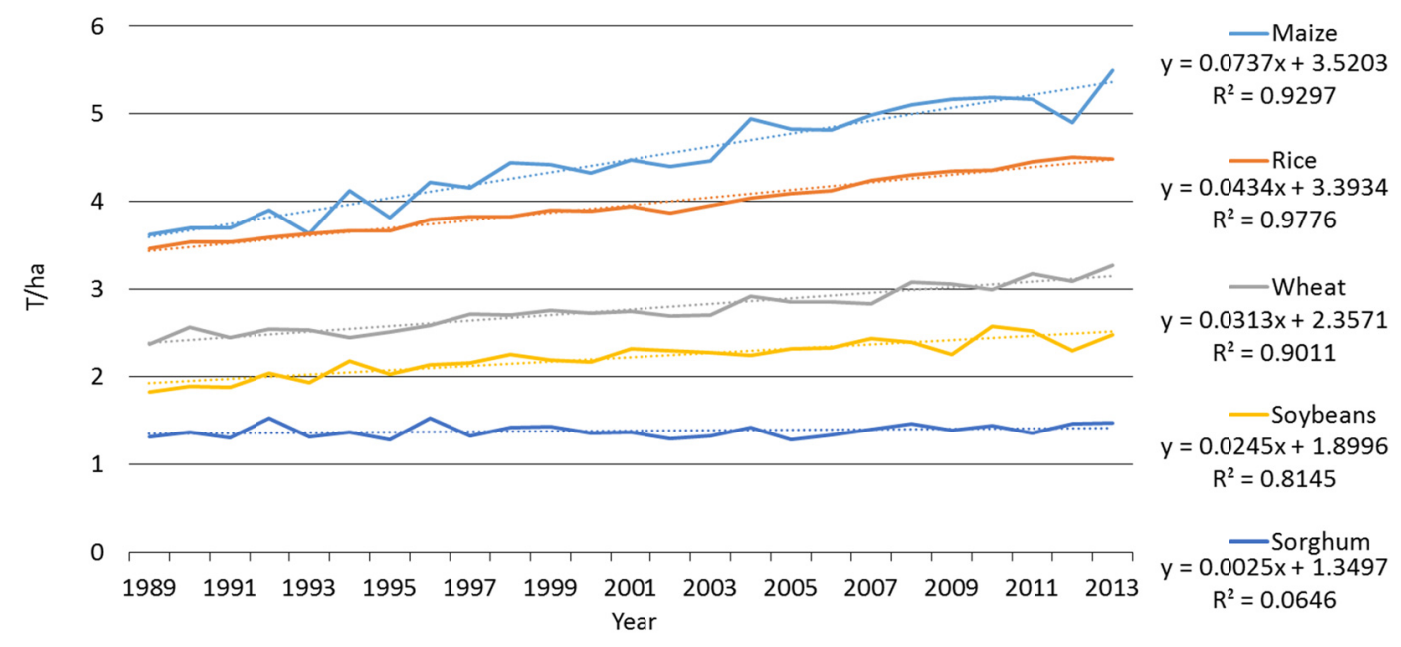

Figure 6. World yield of the top-five grains between 1989-2013 with trend line and equation

That is also the case for Figure 7, which displays the area harvested the world over of the top-five grain crops, and finally Figure 8 displays the production of the top-five grains around the world.

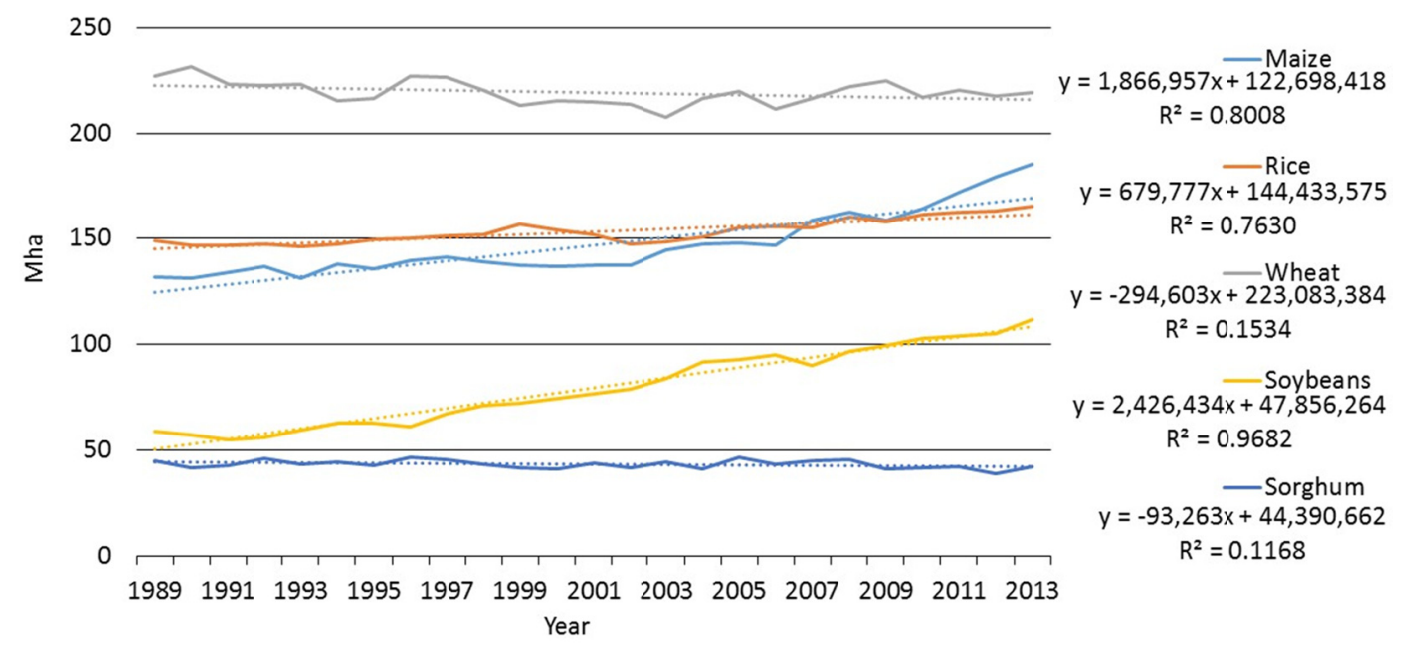

Figure 7. World harvested area for the top-five grains between 1989-2013 with trend line and equation

Each of the Figures have the linear trend line included for each crop, which allows for extrapolation out to 2050 , under the assumption that a linear curve fit is appropriate for the data analyzed. Reviewing the $\mathrm{R}^{2}$ values for each crop's linear curve fit indicates the appropriateness of the linear fit. The $\mathrm{R}^{2}$ values are reported in the Figures just under the equation for the linear curve fit for each crop. 


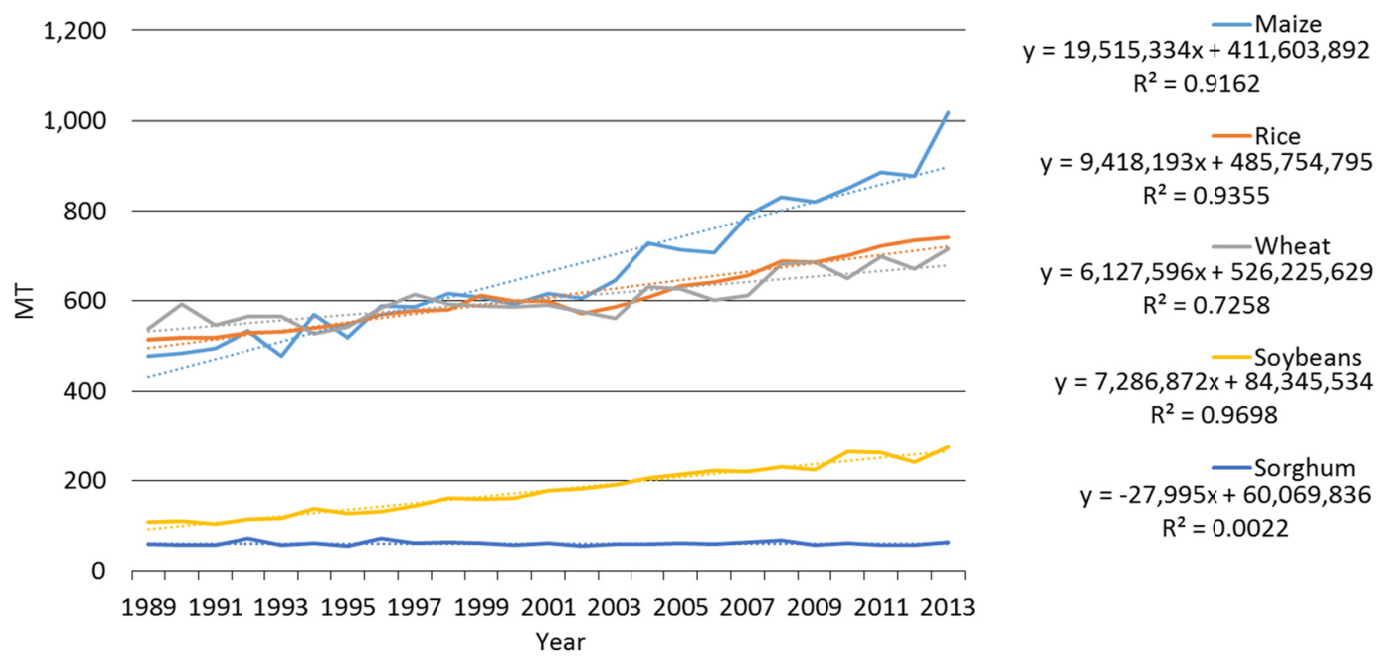

Figure 8. World production for the top 5 grains between 1989-2013 with trend line and equation

\section{Analysis \& Predictions}

Table 1 below summarizes the yields predicted by the linear curve fit for 1989, 2005 and 2013, compares them to the actual reported data, and predicts where the yields by 2050 (FAOSTAT, 2015). The yield values for the top-five crops were compared to reported yield values from a second source (Informa, 2016) and found to differ less than $2 \%$ for maize, wheat and soybeans, but yield of rice is $34 \%$ lower and sorghum is $6-10 \%$ higher as predicted by Informa v/s FAOSTAT. The difference in rice yield and sorghum yield was not apparent from the data nor the associated text in the document in which the data was presented.

Table 1. Yield evolution for the period 1989-2013 and yield prediction for $2050 \mathrm{in} \mathrm{t/ha}$

\begin{tabular}{|c|c|c|c|c|c|c|c|c|c|c|c|}
\hline Crop & $\begin{array}{l}\text { Trend Line } \\
\text { Annual Yield } \\
\text { Change }\end{array}$ & $\begin{array}{l}1989 \\
\text { Trend } \\
\text { Line Yield }\end{array}$ & $\begin{array}{l}1989 \\
\text { Actual } \\
\text { Yield }\end{array}$ & $\begin{array}{l}1989 \\
\text { Error }\end{array}$ & $\begin{array}{l}2005 \\
\text { Trend } \\
\text { Line Yield }\end{array}$ & $\begin{array}{l}2005 \\
\text { Actual } \\
\text { Yield }\end{array}$ & $\begin{array}{l}2013 \\
\text { Trend } \\
\text { Line Yield }\end{array}$ & $\begin{array}{l}2013 \\
\text { Actual } \\
\text { Yield }\end{array}$ & $\begin{array}{l}2013 \\
\text { Error }\end{array}$ & $\begin{array}{l}2050 \\
\text { Est. } \\
\text { Yield }\end{array}$ & $\begin{array}{l}\text { \% Yield } \\
\text { Increase } \\
2005-2050\end{array}$ \\
\hline Maize & 0.074 & 3.52 & 3.62 & $-2.7 \%$ & 4.70 & 4.82 & 5.29 & 5.50 & $-3.8 \%$ & 8.02 & $70.6 \%$ \\
\hline Rice & 0.043 & 3.39 & 3.45 & $-1.8 \%$ & 4.09 & 4.09 & 4.44 & 4.49 & $-1.1 \%$ & 6.04 & $47.8 \%$ \\
\hline Wheat & 0.031 & 2.36 & 2.37 & $-0.7 \%$ & 2.86 & 2.85 & 3.11 & 3.27 & $-4.9 \%$ & 4.27 & $49.3 \%$ \\
\hline Soybeans & 0.025 & 1.90 & 1.83 & $3.9 \%$ & 2.29 & 2.32 & 2.49 & 2.47 & $0.5 \%$ & 3.39 & $48.1 \%$ \\
\hline Sorghum & 0.003 & 1.35 & 1.32 & $2.3 \%$ & 1.39 & 1.29 & 1.41 & 1.48 & $-4.4 \%$ & 1.50 & $8.1 \%$ \\
\hline
\end{tabular}

It is evident from Table 1 that if the linear trend line for yield progression continues out to 2050, then a doubling of production will only happen with an associated increase of the area harvested of each crop.

Table 2 below shows the harvested area predicted by the linear curve fit illustrated from Figure 7 for 1989, 2005, and 2013, compares the harvested area predicted by the trend line to the actual reported data, and predicts where the harvested area will end up in 2050. This data was compared to a second source (Informa, 2016). The data differed less than $2.2 \%$ except the area harvested for sorghum is $8-9 \%$ lower as predicted by Informa $\mathrm{v} / \mathrm{s}$ FAOSTAT. It was not apparent from the data and associated text what caused this difference. 
Table 2. Harvested area evolution for the period 1989-2013 and prediction for harvested area in 2050 in Mha

\begin{tabular}{|c|c|c|c|c|c|c|c|c|c|c|c|}
\hline Crop & $\begin{array}{l}\text { Trend Line } \\
\text { Annual } \\
\text { Change }\end{array}$ & $\begin{array}{l}1989 \\
\text { Trend } \\
\text { Line Area }\end{array}$ & $\begin{array}{l}1989 \\
\text { Actual } \\
\text { Area }\end{array}$ & $\begin{array}{l}1989 \\
\text { Error }\end{array}$ & $\begin{array}{l}2005 \\
\text { Trend } \\
\text { Line Area }\end{array}$ & $\begin{array}{l}2005 \\
\text { Actual } \\
\text { Area }\end{array}$ & $\begin{array}{l}2013 \\
\text { Trend } \\
\text { Line Area }\end{array}$ & $\begin{array}{l}2013 \\
\text { Actual } \\
\text { Area }\end{array}$ & $\begin{array}{l}2013 \\
\text { Error }\end{array}$ & $\begin{array}{l}2050 \\
\text { Est. } \\
\text { Area }\end{array}$ & $\begin{array}{l}\% \text { Area } \\
\text { Increase } \\
2005-2050\end{array}$ \\
\hline Maize & 1.87 & 123 & 132 & $-6.9 \%$ & 153 & 148 & 168 & 185 & $-9.5 \%$ & 237 & $55.1 \%$ \\
\hline Rice & 0.68 & 144 & 149 & $-3.0 \%$ & 155 & 155 & 161 & 165 & $-2.7 \%$ & 186 & $19.7 \%$ \\
\hline Wheat & -0.29 & 223 & 227 & $-1.6 \%$ & 218 & 220 & 216 & 219 & $-1.4 \%$ & 205 & $-6.1 \%$ \\
\hline Soybeans & 2.43 & 48 & 59 & $-18.4 \%$ & 87 & 93 & 106 & 112 & $-4.9 \%$ & 196 & $126.0 \%$ \\
\hline Sorghum & -0.09 & 44 & 45 & $-0.8 \%$ & 43 & 46 & 42 & 42 & $-0.2 \%$ & 39 & $-9.8 \%$ \\
\hline Total & & 582 & 611 & $-4.7 \%$ & 656 & 662 & 693 & 723 & $-4.2 \%$ & 862 & $31.5 \%$ \\
\hline
\end{tabular}

As seen in the bottom right hand field in Table 2, the trend line prediction for area harvested to the top-five grain crops will increase by $31.5 \%$ by 2050 relative to 2005 .

According to Bruinsma (2003), approximately $36 \%$ of the land suitable for crop production worldwide is used in crop production (1.5 of 4.17 billion hectares) in which appears to be 1999 data. Based on the analyzed data from FAOSTAT (2015), the increase in the predicted harvested area between 1999 and 2050, based on the linear curve fit equation, is $39 \%$, which would be an increase of 241 million ha for the top-five grain crops. Assuming the needed increase for other crops is the same, then that will require an increase in the cultivated area worldwide from the 1.5 billion ha in 1999 to 2.1 billion ha in 2050, which will be $48 \%$ of the worldwide available area suitable for crop production, an additional 600 million ha or a $12 \%$-age point increase.

Where will this additional harvested area come from? According to Bruinsma (2003) there are 1.8 billion ha of land suitable for rain fed crop cultivation with yield potential over an acceptable minimum level. Of this land, 90\% of it is in sub-Saharan Africa and Latin America. The estimated amount of additional land available for cultivation in sub-Saharan Africa is more than 700 million ha. However, some of these lands may not be profitable to farm due to lack of available efficient markets for inputs and outputs and due to poor or lacking infrastructure (FAO, 2009).

The calculated actual and predicted production based on the actual yields and harvested area, their trend lines and predictions for 2050, are shown in Table 3.

Table 3. World production of the top-five grains for the period 1989-2013 and prediction for production in 2050 in $\mathrm{kT}$

\begin{tabular}{|c|c|c|c|c|c|c|c|c|c|c|c|}
\hline Crop & $\begin{array}{l}\text { Trend Line } \\
\text { Annual } \\
\text { Change }\end{array}$ & $\begin{array}{l}1989 \\
\text { Trend } \\
\text { Line Prod. }\end{array}$ & $\begin{array}{l}1989 \\
\text { Actual } \\
\text { Prod. }\end{array}$ & $\begin{array}{l}1989 \\
\text { Error }\end{array}$ & $\begin{array}{l}2005 \\
\text { Trend } \\
\text { Line Prod. }\end{array}$ & $\begin{array}{l}2005 \\
\text { Actual } \\
\text { Prod. }\end{array}$ & $\begin{array}{l}2013 \\
\text { Trend } \\
\text { Line Prod. }\end{array}$ & $\begin{array}{l}2013 \\
\text { Actual } \\
\text { Prod. }\end{array}$ & $\begin{array}{l}2013 \\
\text { Error }\end{array}$ & $\begin{array}{l}2050 \\
\text { Est. } \\
\text { Prod. }\end{array}$ & $\begin{array}{l}\text { \% Prod. } \\
\text { Increase } \\
2005-2050\end{array}$ \\
\hline Maize & 19.52 & 432 & 477 & $-9.4 \%$ & 717 & 714 & 886 & 1,018 & $-13.0 \%$ & 1,896 & $164.5 \%$ \\
\hline Rice & 9.42 & 490 & 514 & $-4.7 \%$ & 635 & 634 & 713 & 741 & $-3.8 \%$ & 1,123 & $76.9 \%$ \\
\hline Wheat & 6.13 & 526 & 538 & $-2.3 \%$ & 624 & 627 & 671 & 716 & $-6.2 \%$ & 875 & $40.2 \%$ \\
\hline Soybeans & 7.29 & 91 & 107 & $-15.2 \%$ & 199 & 215 & 264 & 276 & $-4.4 \%$ & 665 & $234.7 \%$ \\
\hline Sorghum & -0.03 & 60 & 59 & $1.4 \%$ & 60 & 60 & 59 & 62 & $-4.6 \%$ & 58 & $-2.5 \%$ \\
\hline Total & & 1,599 & 1,696 & $-5.7 \%$ & 2,234 & 2,249 & 2,594 & 2,813 & $-7.8 \%$ & 4,617 & $106.7 \%$ \\
\hline
\end{tabular}

The predictions look favorable based on the stated need for doubling the crop production by 2050 as a way to feed the increased world population, even with the increase in animal protein people will demand because of increased affluence. However, besides the concern about some of the available land suitable for cropping may not be profitable to farm due to lack of markets and infrastructure, there are also other concerns related to its availability, such as a need to preserve some areas where endangered wild animals live and breed.

\section{Alternative Pathways}

If the harvested area expansion ends up falling short of the predicted area as derived from the linear extrapolation, the question then is: "Is it possible that the yields can increase beyond what is predicted by the linear extrapolation for 2050?" 
To answer this question, a number of parameters must be considered. First, is the rainfall adequate in regions of the world where the yields are trailing other regions of the world with similar soil conditions? Figure 9 shows the average daily rainfall data generated by the GLDAS-1 NOAH model for 1979-2008 (NOAH, 2011).

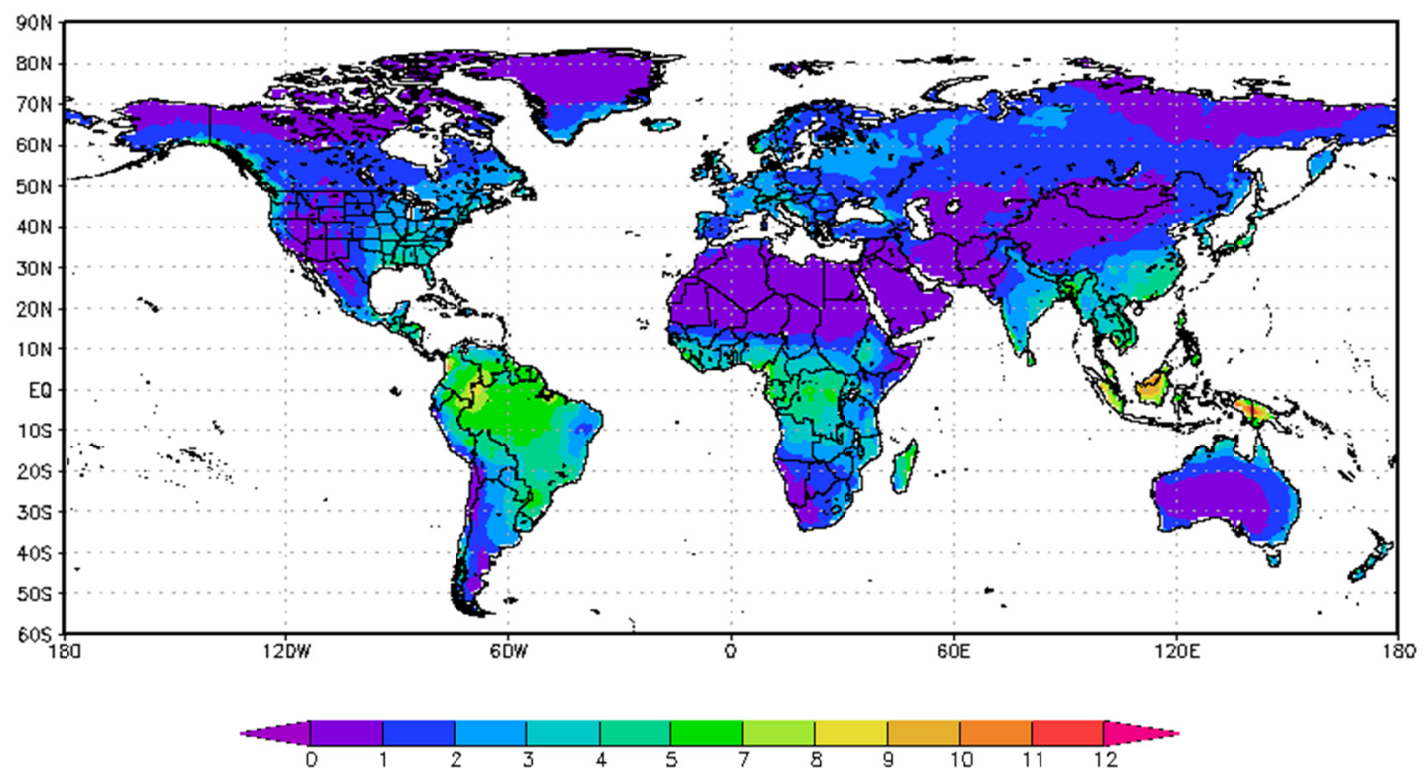

Figure 9. Daily rainfall averages in millimeters based on 1979-2008 data (NOAH, 2011)

The world rainfall map in Figure 9 shows that the daily rainfall averages in areas of the world known for high top 5 grain yields, like the corn belt of the United States of America, Western Europe, the Cerrados of Brazil, and the Humid Pampa region of Argentina, are also present in other parts of the world, such as in large areas of Sub-Saharan Africa and in South-East Asia. Therefore, from a moisture availability point of view, these regions would have the potential to produce yields at similar levels also.

In terms of comparability of climatic conditions, Figure 10 indicates that there are similar conditions in some high yielding areas of the world and in Sub-Saharan Africa, which again indicates that the climatic conditions is not the key reason why yields are as low as they are in these areas.
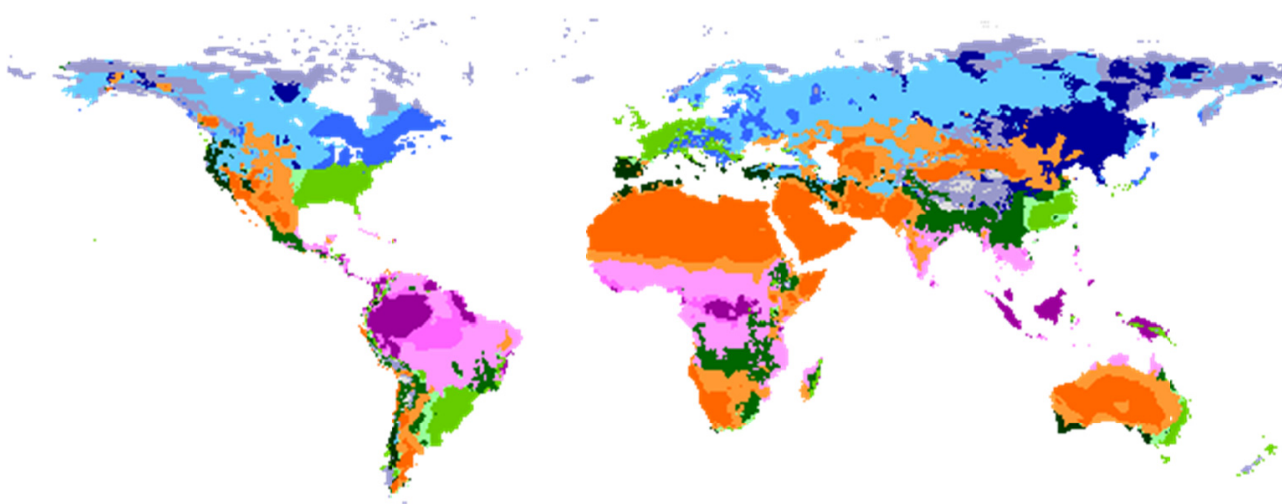

Koeppen's Climate Classification by FAO - SDRN - Agrometeorology Group - 1997

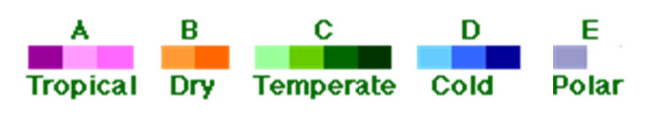

Figure 10. Worldwide climate classification (FAO-SDRN, 1997) 
Against this background, it is reasonable to expect that yields in Sub-Saharan Africa can be raised to the levels of yields in countries like Brazil and Argentina, given similar availability of high quality seeds, sufficient quantities of the necessary fertilizers, and efficient crop production technology.

Is it possible to double the crop production by 2050 if it is not possible to expand the harvested area by 600 million hectares as the predicted precondition if solely the yields predicted by the trend line projections for each region of the world come true? Is it possible to double crop production if the best practices and methods are broadly disseminated across the world and only half of the needed harvested area is added or if the harvested area remains at the 2013 level? Table 4 seeks to shed light on that issue.

Table 4. World production levels in kT by 2050 relative to 2005 \& 2013 with focus on increasing yield and some or no increase in harvested area

\begin{tabular}{lllllll}
\hline Crop & $\begin{array}{l}2005 \text { Actual } \\
\text { Prod. }\end{array}$ & $\begin{array}{l}2013 \text { Actual } \\
\text { Prod. }\end{array}$ & $\begin{array}{l}\text { 2050 Est. Prod. } \\
+300 \text { Mha SSA }\end{array}$ & $\begin{array}{l}\text { Increase relative } \\
\text { to 2005 }\end{array}$ & $\begin{array}{l}\text { 2050 Est. Prod. } \\
2013 \text { area }\end{array}$ & $\begin{array}{l}\text { Increase relative } \\
\text { to } 2005\end{array}$ \\
\hline Maize & 714 & 1,018 & 2,289 & $220.7 \%$ & 1,882 & $163.8 \%$ \\
Rice & 634 & 741 & 1,964 & $209.6 \%$ & 1,542 & $143.1 \%$ \\
Wheat & 627 & 716 & 1,676 & $167.4 \%$ & 1,320 & $110.6 \%$ \\
Soybeans & 215 & 276 & 590 & $175.2 \%$ & 403 & $87.6 \%$ \\
Sorghum & 60 & 62 & 232 & $288.4 \%$ & 110 & $84.1 \%$ \\
\hline Total & 2,249 & 2,813 & 6,751 & $200.2 \%$ & 5,256 & $133.7 \%$ \\
\hline
\end{tabular}

By focusing on yield gains around the world for all crops, through dissemination of best seed genetics for each possible growing region, as well as adopting best practices and methods, including availability of the needed inputs to enhance and defend the yield potential, it is likely that the yield levels will be higher than indicated by the linear extrapolations out to 2050 for each crop and region. An estimate for what the production for each crop could reach by 2050 without any increase in harvested area and half the increase indicated by the trend line yield increases are shown in Table 4 . The yields projected for 2050 by extrapolating the linear yield trend line for each crop in each region were ordered from highest to lowest. The two highest yielding regions were assigned the highest yield, the third highest yielding region was assigned the second highest yield, and regions with fourth-sixth highest yield were assigned the third highest yield. However, Sub-Saharan Africa were always assigned the predicted South American yield for each crop per the discussion above related to the available rain fall and climate zone being similar to the high yielding areas of South America. With this as the basis, it is clear from Table 4 that it is possible to increase the crop production by $134 \%$ without any increase in harvested area relative to 2013. By adding 300 million hectares to crop production in Sub-Saharan Africa, half of the increase in harvested area indicated in Table 2 would be realized, and it would then triple world crop production.

\section{Sustainability of Crop Production Intensification}

The intensification of crop production will have to be done in a way that the land base can sustain in the long run. Proposed methods and processes must leave the utilized resources in an equal or better condition over time to support continued use. The agricultural practices must conserve the land used for crop production and as a feed base for animal production, as well as be commercially viable (Gold, 2009; FAO, 2017).

Agricultural practices have evolved over the last three or four decades. Practices that focus on sustaining the soil have gained increased interest by farmers. Conservation tillage covers a spectrum of such practices and based on the key observation that crop residue left on the soil surface from the time of crop harvest until the following crop has emerged and beyond protects against wind and water soil erosion.

Proper erosion control often requires $30 \%$ or more crop residue cover immediately after planting of the subsequent crop. No-till leaves the soil undisturbed up until planting of the following crop (Nafziger, 2009). However, planting does disturb the crop residue to some degree, so in practice if at least $70 \%$ of the soil is covered with crop residue, then it is considered no-till. The effect of surface residue on soil erosion can be dramatic. Just $30 \%$ of the soil surface covered with plant residue after planting will reduce erosion by $50 \%$ compared to a bare field and 70\% residue coverage will reduce erosion by $90 \%$ (Nafziger, 2009).

Growing cover crops in the period between two cash crops appears to be even more effective in reducing soil erosion. Laloy and Bielders (2009) reports that the soil erosion is reduced by more than $94 \%$ when cover crops are grown as compared to land left untouched with just the stubbles from maize harvest for silage. This indicates 
that the presence of a growing crop in the soil at all times has the potential to significantly reduce soil erosion over having just some amount of crop residue covering the soil surface between growing two cash crops. However, having crop residue covering the soil surface is better than bare soil in controlling erosion. According to SARE (2012), there are additional benefits associated with growing cover crops between two cash crops, such as increased soil health, reduced fertilizer need, moisture conservation, and suppressed weed and disease infestations.

Sustainability of crop production can also be affected by when and how the field activities are executed and the specifications of the machines used. According to DeJong-Hughes (2001), wheel traffic is without a doubt the major cause of soil compaction, and some compaction can be beneficial in dryer years, but any degree of compaction is detrimental in wetter years. The threat of soil compaction is greater today because of the dramatic increase in the size of farm equipment (Duiker, 2004). Yield losses can be severe, up to $98 \%$ in the year of severe compaction in no-till conditions, but the soil will bounce back to yields of $85 \%$ in the second year without tillage and stabilize at around 93\% after that relative to an uncompacted soil (Duiker, 2004). Schneider et al. (2017) reported that removal of root-restricting layers by a form of deep tillage generally resulted in a yield improvement of $20 \%$ relative to deep tillage of fields without a root-restricting layer. Soil compaction can be minimized by avoiding field work when the soil is too wet, by avoiding use of oversized machinery, and by practicing controlled traffic farming, CTF, where the same wheel tracks, or traffic lanes, are used by all machines year after year, leaving the remaining soil uncompacted (Wolkowski, 2008).

\section{Discussion}

The analyzed data and extrapolation thereof indicate that it is possible to raise crop production to the required level to feed the expected world population in 2050, even with an increase in demand for more animal protein in the diet by middle class people, which is expected to increase percentage wise as well. This prediction assumes that the expected yield increases materialize, and a sufficient portion of the stated available land suitable for crop production is brought into production, or that yield spread is reduced between regions of the world through widespread use of most appropriate seed technology for the region, fertilizers, crop production methods, and efficient machinery.

What are indicated as needed to achieve a doubling of crop production by 2050 , can mostly be driven through the political process. It requires political action to put the infrastructure enhancements in place to increase access to efficient markets and low-cost energy, both liquid and gaseous fuels, and electricity. Access to sufficient financing required for acquiring the necessary modern farm machinery, as well as the needed crop production inputs, to attain the world level top yields, will likely require collateral, like assurance that the farm operator can prove ownership of the land that he farms. A policy change in countries where land ownership is not currently sanctioned might be necessary to gain access to the financial markets. Access to best seed technology and sufficient fertilizers suited for the local growing conditions will require trade among nations with limited restrictions, which again relies on political initiative to secure free access to foreign markets to buy and sell what is needed for crop production. In the case of accessing the best seed technology, it can be a question of honoring intellectual property rights between countries, which again requires political attention to be put in place, if it is not already the case.

\section{Conclusions}

A review of the worldwide top-five grain yield and area harvested trends and extrapolation of the trend lines indicate a doubling of crop production is possible by 2050. If the increase in area harvested is not allowed to increase to the extent indicated by the extrapolation of the trend line, then its effect on production can more than be compensated for by broad adopting of appropriate seed technology, equipment technology, best practices, and adequate access to fertilizers. Even a tripling of crop production is possible if half of the indicated increase in harvested area is also realized. This might require politically driven reforms in some areas of the world, where infrastructure and access limit efficient crop production. Increased farm machinery size is an additional threat to yield increases. Targeted use of large machines when the soil is capable of supporting them is indicated. Alternatively, Controlled Traffic Farming could be used to limit soil compaction impact on crop yields.

With higher degrees of automation of functions on modern farm machinery, the leap to full autonomy becomes smaller with time. Considerations should be made for what a machine system for crop production could look like and its potential impact on soil compaction, future yield and crop production sustainability. 


\section{References}

Borlaugh, N. (2007). Feeding a Hungry World. Science, 318(5849), 359. https://doi.org/10.1126/science.1151062

Bourgault, M., Brand, J., Tausz, M., \& Fitzgerald, G. J. (2016). Yield, growth and grain nitrogen response to elevated CO2 of five field pea (Pisum sativum L.) cultivars in a low rainfall environment. Field Crop Research, 196, 1-9. https://doi.org/10.1016/j.fcr.2016.04.011

Bruinsma, J. (2003). World agriculture: Towards 2015/2030, an FAO Perspective. Earthscan Publications, Ltd., London, England. Retrieved February 11, 2016, from http://www.fao.org/docrep/005/y4252e/y4252e00.htm

DeJong-Hughes, J., Moncrief, J. F., Voorhees, W. B., \& Swan, J. B. (2001). Soil Compaction: Causes, effects and control (Document \#612-624-1222). University of Minnesota Extension. Retrieved May 18, 2016, from http://www.extension.umn.edu/agriculture/tillage/soil-compaction

Dong, F., \& Fuller, F. (2010). Dietary Structural Change in China's Cities: Empirical Facts or Urban Legends? Canadian Journal of Agricultural Economics, 58(2010), 73-91. https://doi.org/10.1111/j.1744-7976.2009. 01159.x

Duiker, S. W. (2004). Effects of Soil Compaction. Pennsylvania State University, College of Agricultural Sciences, Agricultural Research and Cooperative Extension. Retrieved May 18, 2016, from http://extension.psu.edu/ plants/crops/soil-management/soil-compaction/effects-of-soil-compaction/extension_publication_file

FAO. (2009). The Special Challenge for Sub-Saharan Africa. High-Level Expert Forum, FAO, Rome. Retrieved December 13, 2015, from http://www.fao.org/fileadmin/templates/wsfs/docs/Issues_papers/HLEF2050_ Africa.pdf

FAO. (2017). The future of food and agriculture-Trends and challenges. FAO, Rome. Retrieved January 7, 2018, from http://www.fao.org/3/a-i6583e.pdf

FAO-SDRN. (1997). Koeppen's Climate Classification. FAO-SDRN Agrometeorology Group. Retrieved May 1, 2016, from http://www.blueplanetbiomes.org/climate.htm

FAOSTAT. (2015). Data download for top 5 grains. Food and Agriculture Organization of the United Nations, Statistics Division. Retrieved November 10, 2015, from http://faostat3.fao.org/download/Q/QC/E

Godfray, H. C. J. (2013). The challenge of feeding 9-10 billion people equitably and sustainably. Journal of Agricultural Science, 152, 2-8. https://doi.org/10.1017/S0021859613000774

Gold, M. V. (2009). Sustainable Agriculture: Information Access Tool. Alternative Farming Systems Information Center, National Agricultural Library, U.S. Department of Agriculture, Beltsville, MD. Retrieved April 10, 2016 , from http://afsic.nal.usda.gov/sustainable-agriculture-information-access-tools-1

Green, H., Broun, P., Cakmak, I., Condon, L., Fedoroff, N., Gonzalez-Valero, J., Graham, I., ... Roulin, A. (2015). Planting seeds for the future of food. Journal of the Science of Food and Agriculture, 96(5), 1409-1414. https://doi.org/10.1002/jsfa.7554

Hatfield, J. L., \& Walthall, C. L. (2015). Meeting Global Food Needs: Realizing the Potential via Genetics $\times$ Environment $\times$ Management Interactions. Agronomy Journal, 107(4), 1215-1226. https://doi.org/10.2134/ agronj 15.0076

Informa. (2016). Acreage and Production Reference-s for US and World. Informa Economics.

Jaggard, K. W., Qi, A., \& Ober, E. S. (2010). Possible changes to arable crop yields by 2050. Philosophical Transactions of the Royal Society of London, 365(1554), 2835-51. https://doi.org/10.1098/rstb.2010.0153

King, T., Cole, M., Faber, J. M., Eisenbrand, G., Zabaras, D., Fox, E. M., \& Hill, J. P. (2017). Food safety for food security: Relationship betweem global megatrends and developments in food safety. Trends in Food Science and Technology, 68, 160-175. https://doi.org/10.1016/j.tifs.2017.08.014

Laloy, E., \& Bielders, C. L. (2009). Effect of intercropping period management on runoff and erosion in a maize cropping system. Journal of Environmental Quality, 39(3), 1001. https://doi.org/10.2134/jeq2009.0239

Martin-Guay, M.-O., Paquette, A., Dupras, J., \& Rivest, D. (2018). The new Green Revolution: Sustainable intensification of agriculture by intercropping. Science of the Total Environment, 615, 767-772. https://doi.org/ 10.1016/j.scitotenv.2017.10.024

Mueller, N. D. (2012). Closing yield gaps through nutrient and water management. Nature, 490, $254-257$. https://doi.org/10.1038/nature11420 
Nafziger, E. D. (2009). Soil Management and Tillage. Illinois Agronomy Handbook (pp. 134-135). Urbana, Illinois: Crop Science Extension \& Outreach, University of Illinois Urbana-Champaign.

Nelson, G. C., Valin, H., Sands, R. D., Havilk, P., Ahmmad, H., Deryang, D., .. Willenbockel, D. (2014). Climte change effects on agriculture: Economic responses to biophysical shocks. PNAS, 111(9), 3274-3279. https://doi.org/10.1073/pnas.1222465110

NOAH. (2011). Mean total precipitation fields (surface rainfall + surface snowfall) from $1 \times 1$ monthly GLDAS- 1 NOAH model over 1979 to 2008. Retrieved May 1, 2016, from http://disc.sci.gsfc.nasa.gov/gesNews/gldas_2_ data_release

Pradhan, P., Lüdeke, M. K. B., Reusser, D. E., \& Kropp, J. P. (2014). Food Self-Sufficieny across Scales: How Local Can We Go? Environmental Science \& Technology, 48, 9463-9470. https://doi.org/10.1021/es5005939

Ray, K. R., \& Foley, J. A. (2013). Increasing global crop harvest frequency: Recent trends and future directions. Environmental Research Letters, 8(4), 4041. https://doi.org/10.1088/1748-9326/8/4/044041

SARE. (2012). Managing Cover Crops Profitably. Sustainable Agriculture Research \& Education, Handbook Series Book 9 (3rd ed.). United Book Press, Inc.

Schneider, F., Don, A., Hennings, I., Schmittmann, O., \& Seidel, S. J. (2017). The effect of deep tillage on crop yield-What do we really know? Soil \& Tillage Research, 174, 193-204. https://doi.org/10.1016/j.still.2017. 07.005

Taheri, F., Azadi, H., \& D’Haese, M. (2017). A World without Hunger: Organic or GM Crops? Sustainability, 9(4), Article No. 580. https://doi.org/10.3390/su9040580

Wolkowski, R., \& Lowery, B. (2008). Soil compaction: Causes, concerns, and cures (Document \# A3367). University of Wisconsin-Extension, Madison, WI. Retrieved May 18, 2016, from http://www.soils.wisc.edu/ extension/pubs/A3367.pdf

\section{Copyrights}

Copyright for this article is retained by the author(s), with first publication rights granted to the journal.

This is an open-access article distributed under the terms and conditions of the Creative Commons Attribution license (http://creativecommons.org/licenses/by/4.0/). 